FACTA UNIVERSITATIS

Series: Economics and Organization Vol. 14, $\mathrm{N}^{\mathrm{o}}$ 1, 2017, pp. 43 - 56

DOI: 10.22190/FUEO1701043V

Preliminary communication

\title{
THE EFFECT OF MEDIA REPRESENTATION ON THE DEVELOPMENT OF BANCASSURANCE IN THE REPUBLIC OF SERBIA
}

\author{
UDC 368.021.1:336.71(497.11)
}

\section{Nevenka Vojvodić-Miljković*}

Erste Bank a.d. Novi Sad, Branch Niš, Serbia

\begin{abstract}
The intense competition among banks, in terms of narrowing the interest margins, has led to an increase in administrative and marketing expenses and has limited the profit margins of traditional banking products. At the same time, there has been a change in the preferences of bank clients in terms of reduced interest in investing in the classic banking products of the deposits-saving character and an increasing interest in investing in various forms of life and voluntary pension insurance. Accordingly, as well as with a number of other developments in the market for financial services in the last two decades, a connection between banks and insurance companies has been formed. This process is known as bancassurance. Bancassurance in its simplest form represents the distribution of insurance products through the branch network of banks as a sales channel. For banks this is a way to increase customer loyalty, the diversity of offers and the source of additional income in the form of a reimbursement paid by the insurer. In bancassurance, insurance companies see a relatively inexpensive sales channel of insurance compared to traditional channels, which allows them better market positioning and easier access to a higher quantity of clients. The largest success that bancassurance has had, is with the sale of life insurance, keeping in mind the similarity with the traditional deposit banking products. Past results of the implementation of bancassurance in the Republic of Serbia are insignificant in comparison to the value achieved on this basis in most EU countries. Apart from the objective factors, such results are caused by the lack of information among the population about the possibilities of purchasing different types of financial services in one place (in a bank) and numerous benefits which such integrated purchasing offers. The success of bancassurance largely depends on the determination of the participants (banks and insurance companies) to present the sales channel through the joint appearance on the market, continuous advertisement in the media, especially those who have access to the widest part of the population. For that reason, special emphasis is given to the influence of media
\end{abstract}

Received October 29, 2016 / Revised February 22, 2017 / Accepted February 27, 2017

Corresponding author: Nevenka Vojvodić-Miljković

Erste Bank a.d. Novi Sad, Branch Niš, 18000 Niš, Serbia

* PhD student Faculty of Economics University of Niš, Serbia

E-mail: nevenka.vojvodic-miljkovic@erstebank.rs 
representation for the faster development of bancassurance, which would result in greater awareness and education of the population on that basis, which can later cause an increase in life and non-life insurance sales, given the size of the client basis and sales capacities of Serbian commercial banks.

Key words: bancassurance, media representation, information

JEL Classification: G21, G22

\section{INTRODUCTION}

The aim of the work is to assess the current level of development of bancassurance (sales channels of insurance through banks) in the Republic of Serbia based on the share of the premium generated by the sales channel of the total premium, the share of income from reimbursements and bank commissions on the basis of representation in insurance sales in total incomes from reimbursements and commissions of the Serbian banking sector for the period 2008-2014 and its current media representation.

The listed figures are negligible in comparison to the average value of subject categories in the member states of the European Union. The basic hypothesis is based on the assumption that greater media coverage of bancassurance in Serbia can contribute to its faster development. Faster development of bancassurance, taking into account the size of the client base of Serbian commercial banks, implies a further increase of signed contracts for insurance, especially life insurance contracts, given that it is usually signed through banks (according to the experiences of the EU member states), which generates multiple benefits that for customers, banks, insurance companies and the country as a whole.

In accordance with the subject of research and the formulated hypothesis, the following methods appropriate for the research area are applied in this work, and those are:

- method of description, whose purpose is to describe the current level of bancassurance development in Republic of Serbia,

- desk research based on available domestic or foreign literature and data collected from various sources (public databases of financial institutions and associations of insurers) has been used with a goal to formulate a theoretical basis for the checking of the hypothesis,

- the interview observation and analogy method are used to supplement the knowledge in the field of market research based on an anonymous survey-questionnaires (empirical data) on the impact of media representation on the further development of bancassurance in the Republic of Serbia.

\section{BANCASSURANCE - TERMS AND DEVELOPMENT}

In terms of more obvious competition on the insurance market, the changed attitude of customers and the development of technology, distribution channels for insurance products are of great importance for the successful operation of insurance companies (Curak \& Jakočević, 2007). While adapting to the market conditions, insurance companies changed the traditional way of work by embracing new ways of marketing. Bancassurance represents a package of 
financial services that includes banking and insurance services at the same time and in the same place (Babić-Hodović, 2003, p. 59-63). It also represents a strategy by which banks and insurers work together, more or less in an integrated way on the markets of financial services, which includes the distribution of insurance products by banks (Swiss Reinsurance Company, 2002, p. 3). Compared to other channels, this channel generates lower costs of insurance sales, as it uses the existing sales and the client infrastructure of banks. In addition, through bancassurance banks can achieve a significant additional source of interest free income without major additional investments, which results in building long-term relationships with clients. Main reasons for the expansion of bancassurance are profit and competition (Avdalović \& Petrović 2016). It is estimated that bancassurance in continental Europe already accounts for 20-30\% in the profit of banks (Agnus, 2002). The banks distribution of insurance is growing faster than through traditional distribution channels sales in developed countries but also in developing countries, first in life, and recently in non-life insurance. The beginnings of the modern development of the concept of bank insurance are linked to the legislative changes in France in 1984, which allowed banks access to the insurance market with permission to sell certain types of insurance through their sales networks. The current concept of bancassurance covers a wide range of detailed contractual relationships between banks and insurance companies and varies from country to country, depending on their demographic, economic and legal organization (Kočović \& Šulejić 2006). For these reasons, there are a variety of models for the implementation of bancassurance and there is no standard model, even within one country. However, even though all of the models of bancassurance have not had identical success in their application, these types of insurance sales have attracted the attention of the sector for financial services in a short time. The reason for this is the recognition of bancassurance by banks and insurance companies as an attractive and simple way to increase profitability, which has gained importance especially in the aftermath of the global economic crisis (Cristea \& Dracea \& Cîrciumaru 2010).

\section{BANCASSURANCE IN THE REPUBLIC OF SERBIA}

The beginning of the development of bancassurance in the Republic of Serbia is linked to the legislation and the Banking Act (Službeni glasnik no 107, 2016) being put into effect, which allows banks to conduct insurance representation services, as well as the Decision on detailed conditions for granting approvals for banks to conduct insurance representations issued by the National Bank of Serbia, as the supervisory authority for the banking and insurance industry (Službeni glasnik no 57, 2016). In the Republic of Serbia, there were 25 insurance companies operating in 2014. Of that number 21 companies deal with insurance business, and only 4 companies deal with reinsurance business. Within the sales network, in addition to the insurance companies and numerous legal and natural persons - broker and insurance agents, another 19 banks participate, which received approval from the National Bank of Serbia for conducting activities of insurance representation (National Bank of Serbia Insurance Sector Reports, 2014). 


\subsection{The share of insurance premiums generated by bancassurance in the total premium in Serbia for the period $2007-2014$}

Based on the data collected from official records (website of the National Bank of Serbia), Table 1 represent data relating to the premium of life, non-life insurance, total insurance premium, the share of life and non-life insurance in the total premium for the period from 2007 to 2014 in the Republic of Serbia. Based on the data submitted by the National Bank of Serbia, Administration for Supervision of Financial Institutions, the Department for supervision of the insurance business $(24.06 .2014,22.09 .2014,10.12 .2015)$ in the same tabular and graphical review the total premiums generated through bancassurance will be shown and its share in total insurance premium for the period from 2007 - 2014 in the Republic of Serbia.

Table 1 The total premiums of life and non-life insurance and the share of bank insurance premium in the total premium for the period 2007 - 2014 (in 000 RSD)

\begin{tabular}{cccccc}
\hline Years & $\begin{array}{c}\text { Total premium } \\
\text { life insurances }\end{array}$ & $\begin{array}{c}\text { Total premium } \\
\text { non-life insurances }\end{array}$ & $\begin{array}{c}\text { Total premium Premium gained } \\
\text { of life and non- } \\
\text { life insurances } \\
\text { through } \\
\text { bancassurance }\end{array}$ & $\begin{array}{c}\text { The share of the } \\
\text { bancassurance premium } \\
\text { in the total premium }\end{array}$ \\
\hline 2007 & 4.939 .508 & 39.840 .510 & 44.780 .018 & $14.460,18$ & $0,03 \%$ \\
2008 & 6.347 .035 & 45.839 .596 & 52.186 .631 & $101.660,13$ & $0,20 \%$ \\
2009 & 7.881 .193 & 45.653 .453 & 53.534 .646 & $302.754,57$ & $0,57 \%$ \\
2010 & 9.352 .714 & 47.168 .218 & 56.520 .932 & $658.194,30$ & $1,164 \%$ \\
2011 & 9.992 .706 & 47.321 .292 & 57.313 .998 & $1.019 .105,86$ & $1,778 \%$ \\
2012 & 11.855 .400 & 49.608 .308 & 61.463 .708 & $1.318 .448,44$ & $2,145 \%$ \\
2013 & 14.065 .458 & 49.976 .051 & 64.041 .509 & $2.076 .588,68$ & $3,242 \%$ \\
2014 & 16.005 .074 & 53.399 .931 & 69.405 .005 & $2.617 .896,32$ & $3,771 \%$ \\
\hline \multicolumn{5}{c}{ Source: Author's illustration (based on data: NBS - Insurance Sector Reports, 2007-2014 } \\
and data submitted at the request of the author NBS - the Administration for Supervision \\
of Financial Institutions, 2014; 2015)
\end{tabular}

The National Bank of Serbia does not disclose information on its official website relating to the amount of insurance premiums earned by bank insurance, as well as the income generated by the banking sector achieved on that basis, but they are received at the request of the author for the purposes of the research. Therefore, the Administration for Supervision of Financial Institutions and the Department for supervision of the insurance business pointed out to the author that the National Bank of Serbia keeps track only of the total insurance premium realizable through bancassurance, without special records of premium life and non-life insurance, which is generated through this channel.

Despite the significant number of banks (19), which are agents of the leading insurance companies in the Republic of Serbia, a large number of insurance agents licensed by bank employees, good conditions in terms of the developed commercial network of banks (branch network, counters and offices) and a large client base of Serbian banks, we can conclude that the share of premiums generated through bancassurance in the total insurance premium is small in spite of the growth of premiums generated by this channel in the total premium from year to year. This further implies that the bancassurance in the Republic of Serbia is on a basic level of development compared to data on the participation of the sales channels in the total premium of life and non-life insurance in the member states of the European Union and some countries that are not member states, but that are relevant for this research, which is represented in Graphic 1 
and Graphic 2 Gross written premium (GWP), that is shown in \% in Graphic 1 and Graphic 2, represents the total premium (direct and assumed) written by an insurer before deductions for reinsurance and ceding commissions. Includes additional and/or return premiums. Direct premiums written represents the premiums on all policies the Company's insurance subsidiaries have issued during the year. Assumed premiums written represents the premiums that the insurance subsidiaries have received from an authorized state-mandated pool or under previous fronting facilities (Insurance glossary, 2016)

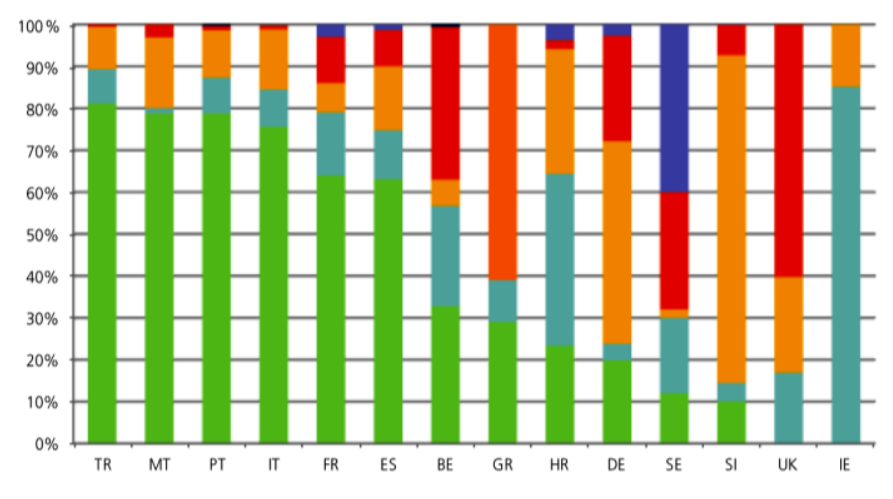

Graph 1 Sales channels for life insurance by country (\% of $\left.\mathrm{GWP}^{2}\right)-2013$ Source: Insurance Europea, 2016, p. 30

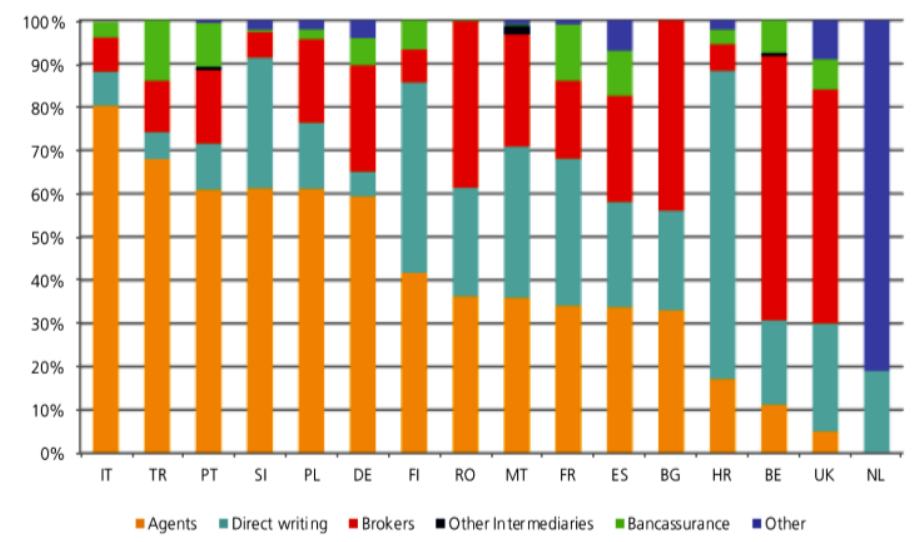

Graph 2 Non-life insurance sales channels by country (\% of GWP) - 2013 Source: Insurance Europea, 2016, p. 31

\footnotetext{
${ }^{2}$ Gross written premium (GWP) is the total premium (direct and assumed) written by an insurer before deductions for reinsurance and ceding commissions. Includes additional and/or return premiums, available on:https://www.irmi.com/online/insurance-glossary/terms/g/gross-written-premium-gwp.aspx

Direct premiums written represents the premiums on all policies the Company's insurance subsidiaries have issued during the year. Assumed premiums written represents the premiums that the insurance subsidiaries have received from an authorized state-mandated pool or under previous fronting facilities. (From EIG 8-K filed Nov 14, 2007) available on: https://en.wikipedia.org/wiki/Gross_premiums_written
} 
If only countries from the Graphic 1 and Graphic 2 were taken into consideration, it could be concluded that bancassurance is the most important distribution channel for selling life insurance. In the selling of life insurance banks have for years had a dominant share especially in Portugal, Spain, France, Italy, Belgium, and more recently in Turkey (81.2\%). In certain countries, this share is much smaller especially in Germany, the UK, the Netherlands and Switzerland (Insurance Europa, 2016, p. 30). When it comes to non-life insurance, bancassurance has a smaller share of the total premium in non-life insurance on the market of the EU member states, considering that the agents and brokers are still the dominant sales channels for the sale of these types of insurances (Insurance Europea, 2016, p. 31). The prevailing attitude in banks states that the sale of non-life insurance can be realized only through cross-selling with banking products, not their own, given that bank employees do not have sufficient knowledge and experience for that kind of sale. Besides, most bank managements are of the opinion that this type of sale generates less income from the sale of life insurance and frequent reports of realized damages, which requires additional administrative expenses.

\subsection{The share of income from reimbursements and bank commissions on the basis of bancassurance in the total income of reimbursements and commissions from the banking sector of the Republic of Serbia for the period 2007-2014.}

Data on the amount of income from commissions based on bancassurance (banks that are licensed by the NBS for performing insurance representation) and their share in the total revenue from reimbursements and commissions of the banking sector in the Republic of Serbia for the period 2007 to 2014 are shown in Table 2.

Table 2 Overview of the share of income from reimbursements and commissions from banks (insurance agents) on the basis of bancassurance in the total income from reimbursement and commission incomes of the banking sector in the Republic of Serbia for the period 2007 to 2014 (in 000 RSD)

\begin{tabular}{cccc}
\hline Years & $\begin{array}{c}\text { Bank commission on } \\
\text { the basis of } \\
\text { bancassurance }\end{array}$ & $\begin{array}{c}\text { Total income of banks } \\
\text { from reimbursements and } \\
\text { commissions }\end{array}$ & $\begin{array}{c}\text { The share of bank incomes from } \\
\text { reimbursements and commissions } \\
\text { on the basis of bancassurance in } \\
\text { total incomes from reimbursements } \\
\text { and commissions }\end{array}$ \\
\hline 2007 & 806.4 & 34.430 .000 & $0.002 \%$ \\
2008 & 12.748 .20 & 39.780 .000 & $0.03 \%$ \\
2009 & 64.322 .50 & 42.080 .000 & $0.15 \%$ \\
2010 & 199.113 .85 & 42.930 .000 & $0.46 \%$ \\
2011 & 335.594 .66 & 46.790 .000 & $0.72 \%$ \\
2013 & 415.248 .88 & 48.240 .000 & $0.86 \%$ \\
2014 & 581.849 .15 & 47.180 .000 & $1.23 \%$ \\
\hline \multicolumn{4}{r}{ Source: Author's illustration (based on data: NBS - Banking Sector Reports, 2007-2014 } \\
and data submitted at the request of the author NBS - the Administration for Supervision \\
\multicolumn{4}{r}{ of Financial Institutions, 2014; 2015) }
\end{tabular}


It is evident that there is a low share of bank income from reimbursements and commissions on the basis of representation in the sale of insurance in comparison to the total income of the banking sector from reimbursements and commissions for the observed period, despite the significant growth dynamics of the revenues from year to year. In the future, commercial banks in Serbia will lose primacy on the market for payments services, with the emergence of new providers for this service. For those reasons, banks will increasingly perform jobs that generate income of interest-free nature (from reimbursements and commissions), such as selling insurance.

\section{MEDiA REPRESENTATION - A FACTOR OF FASTER DEVELOPMENT OF BANCASSURANCE IN THE REPUBLIC OF SERBIA}

For the purpose of accelerating the development of bancassurance in the Republic of Serbia, it is necessary to increase its media representation, so that the general public could get a better insight of this kind of insurance selling. In this regard, defining and implementing the strategy of continuous joint marketing between banks and insurance companies, is a necessary condition for greater promotion of bancassurance. In addition to advertisements in daily newspapers and weekly magazines, on the radio, television and internet portals, it is also desirable to organise press conferences, broadcast reports, interviews and other forms of public appearances by representatives of banks and insurance companies on this issue (Manoy, 2001). The content and scope of marketing activities is the subject of an agreement between the bank and the insurance company and is defined according to the targets set by the action plan (Davis, 2007). In addition, it is necessary to mark and brand the counters in banks and places where employees work - agents in insurance sales by:

- sticking stickers on the front door of the counter hall,

- placing hanging advertisements on the premises of the bank,

- installing neon billboards on glass portals of the banks that will inform the customers of the bank that they can buy insurances of specific insurance companies in the bank,

- setting up promotional material in front of each insurance company's stand, such as flyers about the characteristics of insurance which the insurance company offers, bank flyers that provide information about the new bancassurance sales, brochures with the characteristics of the most frequently purchased types of life and non-life insurances in general, roll ups, posters, flags and others.

In order to determine the influence of media representation on the further development of bancassurance in the Republic of Serbia, a survey was conducted on a sample of 500 respondents with different demographic characteristics with the aim to get a better representation of the population regarding the relevant subject. The data was collected by 50 organisational units of banks throughout the Republic of Serbia, from Subotica to Kursumlija. The results obtained by this survey - the impact of the media representation on the development of bancassurance in the Republic of Serbia will be presented below. On the level of the entire sample, about $74 \%$ of the respondents were male an around $26 \%$ were female (Table 3). When it comes to the age of the respondents, most of them belonged to the age group of 30-60 years (Table 4). 
Table 3 Gender of the respondents

\begin{tabular}{lcccc}
\hline & Frequency & $\%$ & Valid \% & Cumulative \% \\
\hline Male & 372 & 74.4 & 74.4 & 74.4 \\
Female & 128 & 25.6 & 25.6 & 100.0 \\
\hline Total & 500 & 100.0 & 100.0 & \\
\hline
\end{tabular}

Table 4 Age of the respondents

\begin{tabular}{lcrcc}
\hline & Frequency & $\%$ & Valid \% & Cumulative \% \\
\hline Up to 30 years & 101 & 20.2 & 20.2 & 20.2 \\
From 31-40 years & 128 & 25.6 & 25.6 & 45.8 \\
From 41-50 years & 139 & 27.8 & 27.8 & 73.6 \\
From 51-60 years & 101 & 20.2 & 20.2 & 93.8 \\
Over 60 years & 31 & 6.2 & 6.2 & 100.0 \\
\hline Total & 500 & 100.0 & 100.0 & \\
\hline
\end{tabular}

From the aspect of marital status, the highest percentage of respondents are married (76\%), have 2 children (44\%) and live in a household that consists of four members (33\%), as shown in Table 5, 6 and 7.

Table 5 Marital status of the respondents

\begin{tabular}{lcccc}
\hline & Frequency & $\%$ & Valid \% & Cumulative \% \\
\hline Single & 85 & 17.0 & 17.0 & 17.0 \\
Married & 379 & 75.8 & 75.8 & 92.8 \\
Divorced & 36 & 7.2 & 7.2 & 100.0 \\
\hline Total & 500 & 100.0 & 100.0 & \\
\hline
\end{tabular}

Table 6 Number of children

\begin{tabular}{lcccc}
\hline & Frequency & $\%$ & Valid \% & Cumulative \% \\
\hline 1 & 112 & 22.4 & 22.4 & 22.4 \\
2 & 220 & 44.0 & 44.0 & 66.4 \\
3 & 130 & 26.0 & 26.0 & 92.4 \\
4 & 36 & 7.2 & 7.2 & 99.6 \\
5 & 2 & 0.4 & 0.4 & 100.0 \\
\hline Total & 500 & 100 & & \\
\hline
\end{tabular}

Table 7 Number of household members

\begin{tabular}{lcccc}
\hline & Frequency & $\%$ & Valid \% & Cumulative \% \\
\hline 1 & 24 & 4.8 & 4.8 & 4.8 \\
2 & 86 & 17.2 & 17.2 & 22.0 \\
3 & 151 & 30.2 & 30.2 & 52.2 \\
4 & 167 & 33.4 & 33.4 & 85.6 \\
5 & 54 & 10.8 & 10.8 & 96.2 \\
6 & 18 & 3.6 & 3.6 & 100.0 \\
\hline Total & 500 & 100.0 & 100.0 & \\
\hline
\end{tabular}


According to the level of education, the most numerous were the respondents with secondary education $(63 \%)$; respondents with college and university degrees were in about equal numbers, while the lowest number of respondents had an MBA, PhD or only primary education, as shown in table 8.

Table 8 Level of education

\begin{tabular}{lcrrr}
\hline & Frequency & $\%$ & Valid \% & Cumulative \% \\
\hline Primary school & 27 & 5.4 & 5.4 & 5.4 \\
Secondary school & 313 & 62.6 & 62.6 & 68.0 \\
College & 78 & 15.6 & 15.6 & 83.6 \\
University & 74 & 14.8 & 14.8 & 98.4 \\
MBA & 5 & 1.0 & 1.0 & 99.4 \\
PhD & 3 & 0.6 & 0.6 & 100.0 \\
\hline Total & 500 & 100.0 & 100.0 & \\
\hline
\end{tabular}

When it comes to the distribution of the respondents by "total monthly income" the following data was recorded: most respondents have an income of between 20,000.00 and 40,000.00 RSD, respondents with a monthly income of up to 20,000.00 RSD and $40,000.00$ to $60.000,00 \mathrm{RSD}$ occurred in approximately equal numbers, while the lest number of respondents had incomes larger than 100,000.00 RSD, as shown in Table 9.

Table 9 Total monthly income

\begin{tabular}{lcccc}
\hline & Frequency & $\%$ & Valid \% & Cumulative \% \\
\hline Up to 20000 & 103 & 20.6 & 20.6 & 22.9 \\
From 21000 to 40000 & 193 & 38.6 & 38.6 & 59.2 \\
From 41000 to 60000 & 114 & 22.8 & 22.8 & 82.0 \\
From 61000 to 80000 & 43 & 8.6 & 8.6 & 90.6 \\
From 81000 to 100000 & 31 & 6.2 & 6.2 & 96.8 \\
Over 100000 & 16 & 3.2 & 3.2 & 100.0 \\
\hline Total & 500 & 100.0 & 100.0 & \\
\hline
\end{tabular}

The smallest number of respondents stated that their knowledge on bancassurance is very low (4\%) and very high (2\%). Most respondents, $82 \%$ stated that their knowledge, as well as the knowledge of others from their expertise, is very little or bad. Only $12 \%$ of respondents said that their knowledge on bancassurance is high. However, if you take into account that bancassurance is a relatively new channels sale of insurance in the Republic of Serbia, further survey results may be considered valid, bearing in mind that $65 \%$ of respondents said they have a low, high and very high knowledge on bancassurance, which the representative sample represents (Table 10). 
Table 10 Knowledge on bancassurance

\begin{tabular}{lcccc}
\hline & Frequency & $\%$ & Valid \% & Cumulative \% \\
\hline Low & 155 & 31.0 & 31.0 & 31.0 \\
Very low & 20 & 4.0 & 4.0 & 35.0 \\
Little & 255 & 51.0 & 51.0 & 86.0 \\
High & 60 & 12.0 & 12.0 & 98.0 \\
Very high & 10 & 2.0 & 2.0 & 100.0 \\
\hline Total & 500 & 100.0 & 100.0 & \\
\hline
\end{tabular}

When it comes to the amount of advertisements of bancassurance in the media, the majority of respondents, $87 \%$ believe that it is insufficient, which is in accordance with the real situation (Table 11). In 2014 in the Republic of Serbia, 19 banks concluded contracts on representing the insurance companies, and only 5 banks qualified for an advertising campaign about it, within the advertisement of basic bank products (Table 12).

Table 11 Media representation of bancassurance

\begin{tabular}{lcccc}
\hline & Frequency & $\%$ & Valid \% & Cumulative \% \\
\hline Sufficient & 64 & 12.8 & 12.8 & 12.8 \\
Insufficient & 436 & 87.2 & 87.2 & 100.0 \\
\hline Total & 500 & 100.0 & 100.0 & \\
\hline
\end{tabular}

Table 12 Advertisements referring to bancassurance

\begin{tabular}{lcccc}
\hline & Frequency & $\%$ & Valid \% & Cumulative \% \\
\hline None & 411 & 82.2 & 82.2 & 82.2 \\
$1-3$ & 79 & 15.8 & 15.8 & 98.0 \\
$4-5$ & 9 & 1.8 & 1.8 & 99.8 \\
More than 5 & 1 & 0.2 & 0.2 & 100.0 \\
\hline Total & 500 & 100.0 & 100.0 & \\
\hline
\end{tabular}

Most respondents (82\%) did not know to name any advertisement relating to bancassurance. In addition to the clear perception that there is a lack of representation, a need for it is clearly visible form the results.

Table 13 Continued advertising campaign relating to bancassurance

\begin{tabular}{lcccc}
\hline & Frequency & $\%$ & Valid \% & Cumulative \% \\
\hline Yes & 391 & 78.2 & 78.2 & 78.2 \\
No & 109 & 21.8 & 21.8 & 100.0 \\
\hline Total & 500 & 100.0 & 100.0 & \\
\hline
\end{tabular}

The largest percentage of respondents is of the opinion that the best way to advertise bancassurance is through its representation on the television, radio and internet portals at the same time (43\%). A significantly smaller amount of respondents circled individually in separate intervals: TV advertising $23 \%$, radio $17 \%$, Internet advertising $14 \%$, while the remaining $3 \%$ chose another form of advertising (table 14). 
Table 14 Choice of media

\begin{tabular}{lcccc}
\hline & Frequency & \multicolumn{1}{c}{$\%$} & Valid \% & Cumulative \% \\
\hline TV. radio and internet & 216 & 43.2 & 43.2 & 43.2 \\
Radio & 83 & 16.6 & 16.6 & 59.8 \\
TV & 116 & 23.2 & 23.2 & 83.0 \\
Internet & 71 & 14.2 & 14.2 & 97.2 \\
Newspaper & 10 & 2.0 & 2.0 & 99.2 \\
Other forms of public representation & 3 & 0.6 & 0.6 & 99.8 \\
Other (recommendation from an & 1 & 0.2 & 0.2 & 100.0 \\
acquaintance and other) & & & & \\
\hline Total & 500 & 100.0 & 100.0 & \\
\hline
\end{tabular}

A large number of respondents $(63 \%)$ believe that there is a difference when purchasing insurance in a bank and directly in an insurance company (Table 15).

Table 15 The review of respondents on the question: Is there a difference when purchasing insurance in a bank and directly in an insurance company?

\begin{tabular}{lcccc}
\hline & Frequency & $\%$ & Valid \% & Cumulative \% \\
\hline Yes & 317 & 63,4 & 63,4 & 63,4 \\
No & 183 & 36,6 & 36,6 & 100,0 \\
\hline Total & 500 & 100,0 & 100,0 & \\
\hline
\end{tabular}

The majority of respondents (75\%) think that the insurance is more expensive, the process of buying it is slower and so is the process of resolving damage claims in the bank (Table 16). In addition, the factors which determine whether the insurance will be bought in a bank or an insurance company were: the cost of the product and the speed of solving the damages reported (75.4\% of respondents named this factors, Table 16).

Table 16 The existence of differences in purchasing insurance in a bank and in an insurance company

\begin{tabular}{lcccc}
\hline & Frequency & $\%$ & Valid \% & Cumulative \% \\
\hline Price & 151 & 47.6 & 47.6 & 47.6 \\
Expertise level of the staff & 43 & 13.6 & 13.6 & 61.2 \\
Process speed & 35 & 11.0 & 11.0 & 72.2 \\
Speed of resolving damage claims & 88 & 27.8 & 27.8 & 100.0 \\
\hline Total & 317 & 100.0 & 100.0 & \\
\hline
\end{tabular}

Based on these results, we can conclude that the knowledge on bancassurance as a distribution channel of insurance, as well as the media coverage of it is small, whereby the need for continuous informing and a need for a greater level of awareness of the population is perceived on that basis. Keeping in mind the importance of bancassurance for all participants, but also the fact that insurance companies do not want to emphasis any features of the sales channels in particular in the media, a conclusion can be drawn that banks need to give special attention to advertising this insurance sales channel in the up-coming period, primarily through television, radio and internet portals. 
In order to further the development of bancassurance in the Republic of Serbia special attention should be paid to educating and informing the population about this sales channel. The author of this study believes that the education and publicity can be performed simultaneously. An example of this would be advertising campaigns which not only supply information about bancassurance, but also inform the population that there is no difference in purchasing insurance in a bank compared to a traditional distribution channel. The focus of this research was on the results of the general sample. The author believes that we could obtain certain differences in the analysis of the research results if we take into account gender, educational structure of the sample, as well as the place of residence, i.e. a difference of opinion of inhabitants of villages and towns, which could be the subject of an upcoming research.

\section{CONCLUSION}

On the insurance market of the Republic of Serbia, bancassurance, as a channel of insurance distribution, is at the beginning of its development, which the total premium generated via this channel in the total insurance premium represents, as well as the share of revenues from reimbursements and bank commissions on the basis of bancassurance in the total income from reimbursements and commissions of the banking sector in the Republic of Serbia. For most banks, insurance agents, until recently the prevailing attitude was that bancassurance was a low profitable job, due to that; their management did not show greater interest in the development of this sales channel. However, a number of factors such as narrowing interest margins, increased credit risk, a large number of nonperforming loans, increased competition between the banks themselves and the banks and insurance companies in terms of deposits, which results in an increased risk of their outflows, have led to more and more commercial banks in the Republic of Serbia, as a way of ensuring long-term customer loyalty, they see this in the collaboration with the insurers. In addition, in modern conditions there is an emergence of new participants in the market for payment services where banks until recently had primacy. Bearing in mind the factors above, banks are more interested in increasing interest-free incomes such as reimbursements and commissions paid to them by the partner-insurance company for parliamentary activity. Insurance companies through bancassurance achieve easier access to more customers, better market positioning with lower distribution costs compared to traditional sales channels, which further implies greater competitiveness and profitability. Based on the results of the survey about media representation of bank insurance, it can be concluded that the media coverage of this sales channel is insufficient, and it is clearly visible from the results that there is a need for it. The majority of respondents (about $80 \%$ ) believe that in the case of continuous advertising campaigns and media representation, a greater awareness of the population about the possibility of buying insurance in banks would be achieved.

Bearing in mind the significance of bancassurance for all participants, but also the fact that the insurance companies do not have the practice of individual advertising of sales channels, but rather they focus on the advertising of the brand, banks, in the upcoming period, should pay more attention to media promotion of bancassurance. In this way, many of the benefits of this sales channel would be closer presented to the general 
population and, above all, that bancassurance can fully meet the needs of a modern, more demanding customer, to whom, in an accelerated rhythm of life and business, the integrated purchases of various financial services suits, with the possibility of obtaining complex information in one place.

\section{REFERENCES}

Agnus H. (2002) “Bancassurance-knowing and growing with your customers”, 12-14

Avdalović V., Petrović E., Stanković J. (2016) Rizik i osiguranje [Risk and Insurance], Ekonomski Fakultet Niš, 446-448.

Babić-Hodović V. (2003). Bankoosiguranje - konkurencija ili kooperacija bankarstva i osiguranja [Bancassurance-Competition or Cooperation between Banking and Insurance]. Svet osiguranja, 59-63.

Cristea M., Dracea R, Cîrciumaru D. (2010) "The interaction between banking and insurance sectors and their correlation - Case study in Romania", Journal of International Scientific Publication: Economy \& Business, 4(3), sept. 2010, ISSN 1313-2555, 362-373 Retrieved from https://www.scientific-publications. net/download/economy-and-business-2010-3.html.

Curak M., Jakočević D. (2007). Osiguranje i rizici [Insurance and Risks], Edit, Zagreb 2007, 203-209.

Davis I.S. (2007) Bancassurance: The Lessons of Global Experience in Banking and Insurance Collaboration, First published: London, June 2007, VRL KnowledgeBank Ltd, Print production: Patersons (www.patersons.com)

Insurance Europea, (2016). European Insurance in Figures: 2014 data. Retrieved from: http://www.insuranceeurope. eu/sites/default/files/attachments/European\%20Insurance\%20in\%20Figures\%20-\%202014\%20data_0.pdf.

Insurance glossary (2016), Retrieved from:

https://www.irmi.com/online/insurance-glossary/terms/g/gross-written-premium-gwp.aspx.

Kočović J., Šulejić P. (2006). Osiguranje [Insurance], Centar za izdavačku delatnost Ekonomskog fakulteta u Beogradu, Beograd. 544-557.

Manoy K. (2001). Marketing and Distribution Channels in Bancassurance, CEO s Summit of banks and insurance companies of Asia Pacific countries in summit of Asia Business Forum, Singapore.

National Bank of Serbia, Insurance Sector Reports - annual report for 2007, 2008, 2009, 2010, 2011, 2012, 2013, 2014 available on: https://www.nbs.rs/internet/english/60/60_6/index.html,

National Bank of Serbia, Banking Sector-Quarter and Annual Report, annual report for 2007, 2008, 2009, 2010, 2011, 2012, 2013, 2014 available on: https://www.nbs.rs/internet/english/55/55_4/index.html. Accessed on: 15 August 2016

National Bank of Serbia, the Administration for Supervision of Financial Institutions, the Department for supervision of the insurance business, data submitted at the request of the author of the work 24.06.2014, 22.09.2014 and 10.12.2015

Njegomir, V. (2011). Osiguranje [Insurance], Ortomedics book, Novi Sad.350-351.

Službeni glasnik RS [Official Journal of Republic of Serbia], 107/2005.

Službeni glasnik RS [Official Journal of Republic of Serbia] 57/2006.

Swiss Reinsurance Company. (2002). Bancassurance: A Survey of competition between banking and insurance. Sigma 2.

\section{UTICAJ MEDIJSKE ZASTUPLJENOSTI NA RAZVOJ BANKOOSIGURANJA U REPUBLICI SRBIJI}

Intenzivna konkurencija među bankama, u uslovima smanjenja kamatnih marži, dovela je do povećanja administrativnih $i$ marketinških troškova $i$ ograničila profitne margine tradicionalnih bankarskih proizvoda. Istovremeno, došlo je do promena u preferencijama klijenata banaka u pogledu smanjenog interesovanja za ulaganje sredstava u klasišne bankarske proizvode depozitnoštednog karaktera i povećanje intersovanja za investiranje u razne vidove životnih $i$ dobrovoljnih penzionih osiguranja. U skladu sa tim, kao i brojnim drugim dešavanjima na tržištu finansijskih usluga u poslednje dve decenije, došlo je do je do povezivanja banaka i osiguravajućih kompanija. 
Taj proces je poznat kao bankoosiguranje (engl. bancaassurance). Bankoosiguranje u svom najjednostavnijem obliku predstavlja distribuciju proizvoda osiguranja preko poslovne mreže banaka kao kanala prodaje. Za banke je to način povećanja lojalnosti klijenata, raznovrsnosti ponude i izvor dodatnog prihoda u vidu naknade koje naplaćuju od osiguravača. Osiguravajuće kompanije u bankoosiguranju vide relativno jeftin kanal prodaje osiguranja u odnosu na tradicionalne kanale, koji im omogućava bolje tržišno pozicioniranje $i$ lakši pristup većem broju klijenata. Primena bankoosiguranja je najveći uspeh zabeležila u prodaji životnih osiguranja, imajući u vidu sličnost sa tradicionalnim depozitnim bankarskim proizvodima. Dosadašnji rezultati implementacije bankoosiguranja u Republici Srbiji su zanemarljivi u odnosu na dostignute vrednosti po ovom osnovu $u$ većini zemalja EU. Pored objektivnih faktora, takvi rezultati uzrokovani su $i$ nedovoljnom informisanošću stanovništva o mogućnostima kupovine različitih vrsta finansijskih usluga na jednom mestu (u banci) i brojnim prednostima koje takva integrisana kupovina pruža. Uspešnost primene bankoosiguranja u velikoj meri zavisi i od odlučnosti učesnika (banaka i osiguravajućih društava) da predstave taj prodajni kanal kroz zajednički nastup na tržištu, kontinuiranim oglašavanjem u medijima, posebno onim koji imaju pristup najširoj populaciji stanovništva. Iz tog razloga, u radu je poseban akcenat dat uticaju medijske zastupljenosti na brži razvoj bankoosiguranja, koja bi za rezultat imala veću informisanost $i$ edukaciju stanovništva po tom osnovu, što dalje može generisati povećanje prodaje životnih i neživotnih osiguranja, imajući $u$ vidu veličinu klijenske baze i prodajne kapacitete srpskih poslovnih banaka.

Ključne reči: bankoosiguranje, medijska zastupljenost, informisanost 